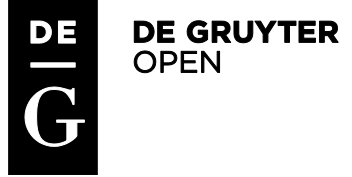

10.1515/topling-2017-0003

\title{
Acquisition of adverbs and pronominal adverbs in a Czech child
}

\author{
Pavla Chejnová \\ Charles University, Czech Republic
}

\begin{abstract}
This article addresses the acquisition of adverbs in a Czech monolingual boy from speech onset until age 6 . This study is based on an analysis of authentic material: a corpus of transcriptions of audio recordings of the child in verbal interaction with adults, and diary records. The acquisition sequence and adverbial type frequency were analysed. The boy acquired adverbs of place first; although direction was acquired before location, location became more frequent. Adverbs relating to time were developed second, and location in time and repetition were the most frequent temporal aspects. Adverbs of degree followed; adverbs related to high degree were more frequently expressed than adverbs related to low degree. Adverbs of manner appeared last, in which adverbs related to a broader evaluative sense prevailed. Adverbs related to cause were manifested mostly by the interrogative proč / why. Interrelation between the acquisition of nominal and verbal categories was found: when the child acquired the category of nominal case and was able to use the construction of preposition + noun, the percentage of adverbs of place decreased. When he acquired the verbal aspect, the percentage of adverbs related to time decreased.
\end{abstract}

Key words

Czech, first language acquisition, adverbs, morphology, child language

\section{Introduction}

The objective of this study was to analyse the acquisition and development of adverbs over a longitudinal timespan in a monolingual Czech boy. Adverbs represent a specific part of speech; carrying various semantic and pragmatic functions, they include various semantic categories, including adverbs related to place, time, manner, degree and cause. Adverbs are autosemantic parts of speech and express both lexical and grammatical meaning. The present study follows several previous studies that focused on the language development of a boy, Přemysl, and some previous results will be commented on in sections 1 and 6. The research is based on an analysis of a parental diary and audio recordings from speech onset until 6 years of age. The research questions are as follows:
1. What was the sequence in which semantic categories of adverbs were acquired?

2. What categories of adverbs were the most frequent?

3. Were any significant errors noted, such as overextension?

From a psycholinguistic point of view, it is necessary to link the linguistic development of the child to his general cognitive development. Results of research oriented towards language acquisition in various languages show that no simple answer can be given to the question of whether and how language and cognition are related during development (Hickmann, 2001, p. 122). The child must interrelate his/her pre-linguistic concepts to linguistic concepts. For example, the perception of space is universal - 
anthropocentric, the speaker / the child understands himself/herself as the central point when referring to spatial relation in the environment. As space dimension is concrete, it is presupposed that its linguistic manifestation will appear sooner than the dimension of time; spatial relations also form a base for development of temporal aspects (e. g. both linear perception of time or cyclic perception of time are based on spatial notions). Cognitive development goes through the same stages in every child, but the child is also influenced by the input he/she receives. In highly inflective languages such as Czech, grammatical meanings are accumulated in endings. Thus, to be able to express e.g. spatial and temporal aspects using a combination of preposition and noun, the child must first have acquired grammatical nominal categories such as gender, number and case. In this study, I will concentrate not only on the acquisition of adverbs alone but also on the interrelation of adverb acquisition and acquisition of inflecting parts of speech such as nouns and verbs.

\section{Previous research}

\subsection{Language development of the target child}

Language development in the target child has already been addressed by Chejnová (2016a). The monograph describes the acquisition of inflective parts of speech (nouns, adjectives, pronouns and verbs) and vocabulary development (the first 1000 lexemes). The analysis was mostly quantitative and largely built on concepts of pre-morphology, protomorphology and modularised morphology / morphology proper (Dressler, ed., 1997; Voeikova and Dressler, eds., 2002; Bittner, Dressler and Kilani-Schoch, eds., 2003; Stephany, and Voeikova, eds., 2009). The results showed that the child acquired most grammatical categories of the Czech language before the age of 3 years and 6 months, at which age he entered the stage of modularized morphology, which is similar to adult models. By age 3.6, the subject had acquired all 7 nominal cases; the first contrast was between the nominative (the subject or nominal part of the verbonominal predicate) and accusative (direct object) in both singular and plural. Dative singular was then added to the paradigm (indirect object, beneficiary), as were locative singular (adverbial - mostly spatial relations) and genitive singular (incongruent attribute and constructions with verbs). Instrumental and vocative were the last to be developed. Plural cases usually developed slightly later than singular cases. In verbs, miniparadigms of the verbs být / to be and mít / to have developed first. The first contrasting forms in lexical verbs were $3 \mathrm{sg}$. present, infinitives in the directive function and past participles (without auxiliaries at first). The first tense acquired was the present tense of imperfective verbs and the future tense of perfective verbs (both synthetic), and periphrastic past and future tenses developed later. The relationship between the development of nominal and verbal paradigms and adverbs will be further addressed in the discussion (section 6).

\subsection{Previous research on adverb acquisition \\ For the Czech language, not much} attention has been paid to the acquisition of adverbs or to language acquisition in general. Pačesová (1968) analysed the language development of her son and quantified his first vocabulary according to parts of speech. Among the first 50 lexemes, adverbs constituted only $2.8 \%$; among the first 100 lexemes; adverbs constituted $2.1 \%$. Pačesová noted that even in later development, adverbs occurred sporadically. Pačesová (1979) also published a monograph focusing on the acquisition on Czech grammar, which was based on observations relating to 100 children aged 2-6 years in crèches and nursery schools and with their families. Following this research, the author concluded that the most frequent category of adverbs was deictic adverbs relating to place and time. Children attempt to express spatial and temporal circumstances as concretely and precisely as possible; they express the contrast between close and distant entities (tady / here versus tam / there) and between immediate and later activities (hned / immediately versus potom / later). Adverbs of manner are acquired later, and Pačesová claims that they occur sporadically (e.g., the adverbs rychle / fast versus pomalu / slowly). Children also express degree: moc / a lot versus málo / a little. Saicová Římalová (2013) notes that 
many adverbial aspects can be expressed using non-verbal means by younger children.

Recent Slovak studies have also reported several interesting findings. Kesselová (2010) observed several spatial distinctions already at the one-word stage: close versus distant, up versus down, and inside versus outside. The concept of space is egocentric and situation-based. However, after passing the one-word stage, children start to use more concrete combinations of prepositions + nouns, which replace deictic adverbs. The category of temporality develops 6-8 months later than the category of location. Kesselová (2010) claims that the category of temporality is derived from the category of location. In Slovak (and also in Czech), the past tense often expresses spatial relations by prefixation: odišiel / he left, literally he from-went; vyšiel / he went out, literally he out-went. The future tense is derived from directive utterances (postavime / we are going to build) (see also Chejnová, 2015). Thus, the first concept of time may also be present in verbs.

Slovak study (Kesselová and Slančová, 2014) analyses video recordings of 4 children from 1 month to age 3.6 and for quantitative research uses the tests of communicative behaviour TEKOS I a II which are the Slovak version of The MacArthur-Bates Communicative Development Inventory (http://laboratorium.detskarec.sk/).

Among the first acquired lexemes with spatial semantics are the deictic lexemes tam / there and tu / here. The child has the central position which is reflected also in adverbs von / out and vonku / outside, preč / away. Thus, the space is at first manifested in the dimension of closeness and distance. Then lexemes denoting vertical dimensions appear: hore / up, dolu / down, and adverbs denoting boundary of space dnu / inwards. Apart from spatial dimension, the adverbs doma / at home and domov / home contain emotional semantics.

Adverbs and their function in dialogue among children were addressed by Kesselová (1999), who audio-recorded children aged 6-10 in various spontaneous dialogues. Adverbs constituted only $3.4 \%$ of all parts of speech, and the index of repetition was high. Several specifics of child language were found:

1. a high frequency of adverbs expressing phases of actions: už / already, eště / still, yet;

2. a high frequency of adverbs denoting day and time of day: dnes / today and ráno / morning. Location in time was more frequent than other temporal aspects, such as frequency and repetition;

3. adverbs denoting direction, often in combination with verbs, denoted motion: von / out, preč / away, dolu / down. Direction was more frequent than location, and starting point (zdola / from below) was expressed rarely;

4. among adverbs of manner, the most frequent were those with a broader evaluative sense (dobre / well versus zle / badly);

5. among adverbs of degree, adverbs of higher degree prevailed, showing hyperbolization.

The studies mentioned above and the present study focused on the production of adverbs by children but did not analyse the real understanding of their content. However, children may use an adverb even if they do not know its precise meaning. Clark (1971) examined how children between 3 and 5 years of age understand the meanings of the temporal adverbs before and after. Children understood the adverb before earlier than the adverb after, and for some time, they interpreted after as if it meant before. Thus, children develop temporal meaning gradually. Several studies focussing on time adverbs or time conjunctions were aimed at interpreting the discrepancy between understanding and production (e.g., Amidon and Carey, 1972; Barrie-Blackley, 1973; Brown and French, 1976; Coker, 1978). French and Nelson (1983, cf. Carni and French, 1984) proposed that children may be able to use relational terms correctly when they understand the context. However, in comprehension tasks, the context is not known; thus, these tasks are more difficult. Carni and French (1984, p.402) suggest that cognitive ability rather than lexical knowledge develops. However, even in production, errors may occur. Mandić 
(2011) analysed the language of Serbian children aged from 1.6 to 4 years and noted several cases of the overextension of temporal adverbs; e.g., with the adverbs sutra / tomorrow, sinoć / last night, prekjuče / the day before yesterday and posle / after. Harner (1975) also proved that the understanding of adverbs yesterday and tomorrow varies with age in children aged 2, 3 and 4 years. Although tomorrow was used to refer to future events, yesterday was used to refer to times other than this day, including the past. Thus, the usage of this adverb may not fully correspond to adult usage.

\section{Data}

The source of data used is a corpus of child language that has been collected since the onset of speech of a boy, Přemysl, until he was six years old. A study based on one child's language development is limited in its scope, but psycholinguistically oriented research shows that all children go through the same stages of development (Piaget and Inhelder, 1969), although the age at which children enter particular stages can differ over several months, so our descriptive study can illustrate the general sequence of development.

Přemysl is a Czech-speaking monolingual boy living in Prague and is the only child in his family. His parents obtained university-level education. The boy did not acquire Standard Czech (a prestigious and official language variety) but a substandard variety termed Common Czech, which is spoken by his caregivers. Common Czech differs from Standard Czech significantly in morphology, especially regarding inflectional endings (Neustupný and Nekvapil, 2003). The boy was a late talker, and at the beginning, it was more suitable to use a handwritten diary to record new phenomena in his oral production. Based on the diary data, a database comprising the first 1000 lexemes of his speech was obtained in chronological order. From the age of 2.8, when speech became intelligible and frequent, the boy was audio-recorded once a month, and after he reached the age of 3.3 , I recorded the boy twice each month for 30 minutes in his home in interaction with his adult caregivers. The audio recordings were transcribed by the author according to the CHAT method, which is used in the CHILDES (Child Language Data Exchange System) database (MacWhinney and Snow, 1985; MacWhinney and Snow, 1990; http://childes.psy.cmu.edu).

The recordings were made during routine daily activities, and there was no elicited production aimed at particular language phenomena. Finally, 21,406 utterances of the child were analysed. Age is indicated by year and month (2.8 indicates 2 years and 8 months).

\begin{tabular}{|c|c|c|c|c|c|c|c|c|c|c|c|c|c|c|c|}
\hline \multirow{2}{*}{\multicolumn{2}{|c|}{$\begin{array}{l}\text { age } \\
\text { utterances }\end{array}$}} & 2.8 & \multirow{2}{*}{\multicolumn{2}{|c|}{$\begin{array}{l}2.9 \\
386\end{array}$}} & 2.10 & 2.11 & 3.0 & \multirow{2}{*}{\multicolumn{2}{|c|}{$\begin{array}{l}3.1 \\
302\end{array}$}} & \multirow{2}{*}{$\begin{array}{l}3.2 \\
279\end{array}$} & \multirow{2}{*}{$\begin{array}{l}3.3 \\
422\end{array}$} & \multirow{2}{*}{$\begin{array}{l}3.4 \\
503\end{array}$} & \multirow{2}{*}{$\begin{array}{l}3.5 \\
560\end{array}$} & \multirow{2}{*}{$\begin{array}{l}3.6 \\
515\end{array}$} & \multirow{2}{*}{$\begin{array}{l}3.7 \\
679\end{array}$} \\
\hline & & 303 & & & 289 & 268 & 339 & & & & & & & & \\
\hline 3.8 & 3.9 & 3.10 & & & 4.0 & 4.1 & 4.2 & 4 & & 4.4 & 4.5 & 4.6 & 4.7 & 4.8 & 4.9 \\
\hline 598 & 525 & 545 & 5 & & 511 & 536 & 753 & & 5 & 602 & 591 & 527 & 518 & 576 & 770 \\
\hline 4.10 & 4.11 & 5.0 & 5.1 & 5.2 & 5.3 & 5.4 & 5.5 & 5.6 & 5.7 & 5.8 & 5.9 & 5.10 & 5.11 & 6.0 & total \\
\hline 630 & 467 & 454 & 629 & 567 & 575 & 574 & 626 & 595 & 679 & 633 & 493 & 391 & 613 & 524 & 21406 \\
\hline
\end{tabular}

Table 1: Number of analysed utterances

\section{Methodology and procedures}

The objective of the present study was to analyse the adverbs that occurred in the boy's oral productions. First, the occurrences of adverbs in the handwritten diary, their percentage among other parts

of speech, and their typology, semantic and pragmatic aspects will be commented on. Then, a quantitative analysis of all adverbs that occurred in the audio recordings from age 2.8 until age 6.0 will be presented, focusing on the frequency and acquisition sequence of the adverbs. Occurrences of adverbs related to time, place, manner, degree, cause and predicatives, together with more specific semantic types, will be commented on. A type-token ratio will be used to quantify the lexical diversity of adverbs.

Adverbs are a non-inflectional part of 
speech in Czech but can sometimes express comparatives and superlatives (e.g. some adverbs of manner and degree). Adverbs typically modify verbs, adjectives or other adverbs; when specifying circumstances, they are also called circumstantives. Such adverbs can express circumstances directly (jít domů / to go home) or can function as substitutes (jít tam / to go there); such substitutional adverbs are called pronominal adverbs and were included in the analysis. In this study, the adverbs are classified into the following categories (classification based on Karlík et al., 2002, pp.338-340 and Komárek et al., 1986, p.188; examples are taken from the target child's language corpus):

1. Adverbs of place answer the questions where, where to, where from, which way (tam / there, daleko / far away, dolů / down, pryč / away, nahoru / upwards).

2. Adverbs of time answer the questions when, since when, till when, how long, how often (dnes / today, ted' / now, porád / always, pak / then, nejdrív / at the earliest); some time adverbs can have various semantic characteristics and multiple functions and will therefore be commented on in greater detail (už / already, yet, any more, as early as...., ještě / still, yet, as late as, even more, once again...). Adverbs expressing repetition (zase, znova / again) are included in this category.

3. Adverbs of manner answer the question how (dobre / well, blbě / stupidly, obráceně / the other way around, nějak / somehow, takhle / this way).

4. Adverbs of degree express measure, quantity, intensity (trochu / a little bit, moc / very much, úplně / totally, jenom / only, málo / not much).

5. Adverbs of cause answer the question why, what is the cause, what is the purpose (schválně / deliberately, proč / why). It should be noted here that the semantics of this group is the most diverse, expressing a wider variety of meanings than simple cause (e.g. schválně expresses intention); adverbs of cause are generally infrequent even in adult language.

6. Predicatives are adverbs that are used in the nominal part of the verbonominal predicate. They include modal adverbs, which express the possibility or necessity of some action or process (je potřeba / it is necessary), and state adverbs, which express a state of affairs (je škoda / it is a pity, je mi to líto / I feel sorry).

7. I added a separate category to those listed above for adverbs with a rather specific function: adverbs expressing addition or inclusion (taky / too, dohromady / together). The lexeme taky / také is classified as an adverb when expressing addition of information but as a particle when used to modify expressivity: Co má také dělat! What should he do then! The particle use was not recorded in our sample.

The development of adverbs in the first six years of the child's language ontogenesis will be analysed according to this classification; the first occurrence and semantic function of the adverbs will be commented on.

\section{Limitations of the study}

The study is based on analysis of one child's authentic oral productions. Authentic speech production in the form of audio recordings provides information in the context in which a particular language phenomenon occurs, and it also enables the researcher to evaluate the level of a child's language use at a particular stage. It is possible to record occurrences of a new language phenomenon and analyse its productivity and functionality in following stages of development. "Natural speech samples can provide rich sources of evidence on children's language knowledge, but they are inherently limited. Specific constructions may not occur in a particular child's language sample simply because the pragmatic or cognitive context of the 


\begin{tabular}{|l|l|l|l|l|}
\hline & 50 lexemes & 100 lexemes & 500 lexemes & 1000 lexemes \\
\hline age & 1.11 .28 & 2.2 .1 & 2.7 .15 & 2.11 .3 \\
\hline nouns & 82 & 90 & 66 & 56 \\
\hline adjectives & & & 6.8 & 11.7 \\
\hline pronouns & & & 1.2 & 1.9 \\
\hline numerals & 6 & 3 & 1.6 & 2.2 \\
\hline verbs & 4 & 2 & 15.6 & 19.8 \\
\hline adverbs & & & 2.6 & 3.5 \\
\hline prepositions & & & 0.8 & 0.9 \\
\hline conjunctions & & 5 & 0.6 & 0.5 \\
\hline $\begin{array}{l}\text { particles } \\
\text { interjections }\end{array}$ & 8 & 4.8 & 0.5 \\
\hline
\end{tabular}

Table 2: Parts of speech in the target child's vocabulary in \%

situation hasn't motivated them" (Lust, 2006, p.133). To prevent omission of some adverbs that the child was able to use but were not recorded during the audio recording sessions, a handwritten diary was still used to record new phenomena in the child's oral productions. Handwritten diary data have shown that audio recordings reflect the active usage of adverbs and no significant differences were found in the parental diary and the audio recordings.

The study is limited in its scope due to the fact that only one child's language development has been analysed. In this sense, the present study follows the tradition of case studies on the acquisition of grammatical development (nominal and verbal categories) in typologically different languages, the international Crosslinguistic project on pre- and protomorphology in language acquisition (Dressler, ed., 1997; Voeikova and Dressler, eds., 2002; Bittner, Dressler and Kilani-Schoch, eds., 2003; Stephany, and Voeikova, eds., 2009).). Each study typically included longitudinal recordings of one or two children during their early stages of development. The analysed languages included agglutinative, inflectional and isolating languages; however, Czech was not included. The results suggest that children acquiring highly inflective languages focus more on morphological factors, which play a crucial role in their respective languages for expressing relations between sentence elements. Thus, Czech will illustrate the development of highly inflective language in which the child also has morphological devices available to express spatial, temporal and causal relations. In the original cross-linguistic project, adverb acquisition was beyond the scope, but in
Czech, adverbs are an autosemantic part of speech, carrying both semantic and grammatical meaning, so their usage may further illustrate the process of constructing the grammatical competence of the child.

Another limit is that parental input has not been analysed. The child received input from several adults and also media and from the age of 4 has attended nursery school, so, the adult language recorded is only a small part of the language input that the child has been receiving.

The last limitation is in the fact that only actively used lexemes were analysed; the understanding of adverbs was not tested. There is usually a difference in active and passive vocabulary so it can be presupposed that passive knowledge may include some lexemes that were not actively used. On the other hand, sometimes children use lexemes without proper understanding, or they use them in the larger sense (overextension) or in the narrower sense (underextension). Although passive knowledge is more difficult to access, overextension is manifested in active usage and can illustrate some of the problems with understanding that the child might have.

\section{Results}

\subsection{Adverbs in the first lexicon}

Based on the handwritten diary, the 1000 lexemes in Premysl's oral productions were listed and further analysed. Table 2 presents the percentages of each part of speech among the first 50, 100, 500 and 1000 actively used lexemes of the target child (Chejnová, 2016a). Age is indicated by year, month and day. As illustrated, adverbs were among the least frequently occurring parts of speech. 
I will focus here on the semantic aspects of the first adverbs in greater detail because, as proven by the analysis of their further development, these adverbs continued to occur at high frequency throughout the child's pre-school age.

\begin{tabular}{|c|c|c|c|c|c|c|c|c|c|c|}
\hline $\begin{array}{l}1- \\
100\end{array}$ & $\begin{array}{l}101- \\
200\end{array}$ & $\begin{array}{l}201- \\
300\end{array}$ & $\begin{array}{l}301- \\
400\end{array}$ & $\begin{array}{l}401- \\
500\end{array}$ & $\begin{array}{l}501- \\
600\end{array}$ & $\begin{array}{l}601- \\
700\end{array}$ & $\begin{array}{l}701 \text { - } \\
800\end{array}$ & $801-900$ & $\begin{array}{l}901- \\
1000\end{array}$ & all \\
\hline 2.2 .1 & 2.3 .22 & 2.6 .1 & 2.6 .22 & 2.7 .15 & 2.8 .1 & 2.8 .16 & 2.9 .13 & 2.10 .12 & 2.11 .3 & age \\
\hline $\begin{array}{l}2 \\
\text { tam } \\
\text { kam }\end{array}$ & $\begin{array}{l}1 \\
\text { pryč }\end{array}$ & $\begin{array}{l}4 \\
\text { pak } \\
\text { ven } \\
\text { venku } \\
\text { už }\end{array}$ & $\begin{array}{l}4 \\
\text { trošku } \\
\text { málo } \\
\text { dost } \\
\text { taky }\end{array}$ & $\begin{array}{l}2 \\
\text { vysoko } \\
\text { úplně }\end{array}$ & $\begin{array}{l}3 \\
\text { moc } \\
\text { dál } \\
\text { ještě }\end{array}$ & $\begin{array}{l}7 \\
\text { honem } \\
\text { kde } \\
\text { tady } \\
\text { hodně } \\
\text { jak } \\
\text { dolů } \\
\text { mokro }\end{array}$ & $\begin{array}{l}4 \\
\text { naruby } \\
\text { ted'ka } \\
\text { tu } \\
\text { zase }\end{array}$ & $\begin{array}{l}5 \\
\text { doopravdy } \\
\text { obráceně } \\
\text { jinak } \\
\text { jenom } \\
\text { radši }\end{array}$ & $\begin{array}{l}3 \\
\text { tak } \\
\text { daleko } \\
\text { dneska }\end{array}$ & 35 \\
\hline
\end{tabular}

Table 3: Adverbs in the first vocabulary of the target child

All adverbs that occurred in the target child's oral productions among every 100 newly acquired lexemes are listed in Table 3 . The very first adverbs were adverbs of place: tam / there (denoting location or direction) kam / where to; pryč / away (denoting location or direction); ven / out; venku / outside; vysoko / high, up (denoting location); kde / where; tady, tu / here; doli / down (denoting direction); and daleko / far away. Thus, included among the very first adverbs of place were pronominal deictic adverbs with broad functions. From the very beginning, the child was able to distinguish between location and direction and between assertive and interrogative meanings.

Adverbs relating to time appeared slightly later. Early adverbs of time primarily denoted location in time: pak / then, later; $\operatorname{ted}^{\prime}(\mathrm{ka})$ / now; and dnes(ka) / today; or achievement: už / already.

Adverbs related to degree were first used slightly later than the first used adverbs of time: The child primarily distinguished between low and high degree: trošku / $a$ little bit (diminutive); málo / little, not much; moc, hodnè / very much, a lot; and jenom / only; or expressed achievement: dost / enough and úplně / completely.

Among the most frequently used adverbs throughout the child's pre-school age was taky / too, which denotes addition or inclusion:

age 2.8 .15

(1) je to taky umytý be-3sg. present + it-nom. sg. + adv. + washed-nom.sg. neuter Common

Czech

'it is washed too'

Adverbs that can be used in several functions appeared in the child's speech to denote repetition; e.g. the comparative form of adverbs of place was correctly used: dál / further on, meaning go on: číst dál / go on reading; the temporal adverb ještě (substandard pronunciation eště) was used to denote repetition or continuation: eště kousek / one more piece, eště kreslit / continue drawing; and the adverb zase / again was used first slightly later.

Adverbs of manner appeared latest among all the adverbial categories: honem / quickly (colloquial); jak / how; naruby / inside out; doopravdy / really; (v)obráceně / upside down; tak(hle) / so, in this manner; jinak / in other way; and radši / better (meaning would rather, had better). One predicative adverb of state appeared: mokro / wet. The category of predicatives was generally rare in our corpus because the child preferred to use adjective forms that are also more frequent than predicatives in verbonominal predicates in adult speech. In summary, in the child's very first vocabulary, adverbs appeared first in the following sequence: adverbs of place (direction earlier than location), adverbs of time (denoting location in time, achievement and repetition), and adverbs of degree (low and high degree). Adverbs of manner appeared last. Pronominal 
adverbs of place (kde / where, kam / where to, tam / there, tady / here) with deictic function frequently occurred.

5.2 Development of adverbs in the child's speech between 2.8 to 6.0 5.2.1 Frequency of adverbial types

In Table 4, the frequency of adverbial types is quantified as percentages. From age 2.8 to age 3.6 , the child was at the protomorphological stage. During this stage, children detect and reconstruct or creatively construct morphological patterns of analogies or of first rules. Since age 3.6, Přemysl actively used an adult-like Czech grammar and acquired most nominal and verbal categories. Whereas in the pre-morphological stage, the most frequent adverbs were adverbs of place (see section 5.1), in the protomorphological stage, both adverbs of place and adverbs of time were among the most frequent. Frequency is counted as number of lemmas rather than the number of tokens. The number of adverbs of manner and degree was lower in most audio recordings. Adverbs of cause were represented mostly by the interrogative proč / why, and adverbs denoting addition were represented mostly by the adverb taky / too.

The same tendencies were also manifest during later development, and adverbs of place and time were the most frequent. Adverbs in the category of predicatives appeared. In general, in the stage of morphology proper / modularized morpholgy (approximately after age 3.6), the number of adverbial lexemes increased. In addition, the number of adverbs of manner increased after age 4.6, although this increase was irregular. Adverbs of degree were more frequent from age 4.9. The types of adverbs used will be discussed in greater detail in sections 5.2.2 - 5.2.8.

\begin{tabular}{|l|l|l|l|l|l|l|l|l|l|l|l|l|}
\hline age & 2.8 & 2.9. & 2.10 & 2.11 & 3.0 & 3.1 & 3.2 & 3.3 & 3.4 & 3.5 & 3.6 & 3.7 \\
\hline place & 53.8 & 33.3 & 27.3 & 27.3 & 40 & 33.3 & 33.3 & 44 & 35 & 26.7 & 29 & 34.5 \\
\hline time & 15.4 & 44.4 & 27.3 & 45.5 & 46.7 & 40 & 22.2 & 24 & 45 & 30 & 25.8 & 27.6 \\
\hline manner & 15.4 & 11.1 & 27.3 & 9.1 & 6.7 & 6.7 & 27.8 & 16 & 5 & 20 & 16.1 & 17.2 \\
\hline degree & 7.7 & & 9.1 & 9.1 & & 6.7 & 5.6 & 12 & 10 & 16.7 & 22.6 & 13.8 \\
\hline cause & & & & & & 6.7 & 5.6 & & & 3.3 & 3.2 & 3.4 \\
\hline addition & 7.7 & 11.1 & 9.1 & 9.1 & 6.7 & 6.7 & 5.6 & 4 & 5 & 3.3 & 3.2 & 3.4 \\
\hline total & 13 & 9 & 11 & 11 & 15 & 15 & 18 & 25 & 20 & 30 & 31 & 29 \\
\hline
\end{tabular}

Table 4: Frequency of adverbial types \%

\footnotetext{
1 Total number of lemmas $=100 \%$
} 


\begin{tabular}{|l|l|l|l|l|l|l|l|l|l|l|l|l|}
\hline age & 3.8 & 3.9. & 3.10 & 3.11 & 4.0 & 4.1 & 4.2 & 4.3 & 4.4 & 4.5 & 4.6 & 4.7 \\
\hline place & 29.7 & 29 & 33.3 & 40.7 & 26 & 43.3 & 46.2 & 43.6 & 36.7 & 39.4 & 35.7 & 21.7 \\
\hline time & 32.4 & 38.7 & 36.4 & 25.9 & 40 & 26.7 & 28.2 & 33.3 & 36.7 & 24.2 & 25 & 34.8 \\
\hline manner & 21.6 & 9.7 & 9.1 & 11.1 & 14 & 13.3 & 7.7 & 7.7 & 10 & 12.1 & 21.4 & 21.7 \\
\hline degree & 10.8 & 12.9 & 12.1 & 14.8 & 14 & 10 & 12.8 & 10.3 & 10 & 18.2 & 7.1 & 17.4 \\
\hline cause & 2.7 & 3.2 & 3 & 3.7 & 2 & 3.3 & 2.6 & 2.6 & 3.3 & 3 & 3.6 & 2.2 \\
\hline predicatives & & 3.2 & 3 & & 2 & & & & & & 3.6 & \\
\hline addition & 2.7 & 3.2 & 3 & 3.7 & 2 & 3.3 & 2.6 & 2.6 & 3.3 & 3 & 3.6 & 2.2 \\
\hline total & 37 & 31 & 33 & 27 & 50 & 30 & 39 & 39 & 30 & 33 & 28 & 46 \\
\hline
\end{tabular}

Table 4: Continuation

\begin{tabular}{|l|l|l|l|l|l|l|l|l|l|l|l|}
\hline age & 4.8 & 4.9 & 4.10 & 4.11 & 5.0 & 5.1 & 5.2 & 5.3 & 5.4 & 5.5 & 5.6 \\
\hline place & 31.6 & 28.1 & 22.4 & 22.7 & 25 & 33.3 & 27.9 & 22 & 25.5 & 29.7 & 25 \\
\hline time & 35.1 & 26.3 & 32.7 & 36.4 & 20 & 27.1 & 32.6 & 28 & 34 & 29.7 & 33.3 \\
\hline manner & 14 & 21.1 & 14.3 & 18.2 & 27.5 & 10.4 & 18.6 & 24 & 14.9 & 18.9 & 14.6 \\
\hline degree & 14 & 17.5 & 22.4 & 13.6 & 20 & 22.9 & 14 & 20 & 17 & 13.5 & 20.8 \\
\hline cause & 1.8 & 1.8 & 2 & 2.3 & 2.5 & 2.1 & 2.3 & 2 & 2.1 & 5.4 & 2.1 \\
\hline predicatives & & 3.5 & 2 & 2.3 & 2.5 & 2.1 & 2.3 & 2 & 2.1 & & 2.1 \\
\hline addition & 3.5 & 1.8 & 4.1 & 4.5 & 2.5 & 2.1 & 2.3 & 2 & 4.3 & 2.7 & 2.1 \\
\hline total & 57 & 57 & 49 & 44 & 40 & 48 & 43 & 50 & 47 & 37 & 48 \\
\hline
\end{tabular}

Table 4: Continuation

\begin{tabular}{|l|l|l|l|l|l|l|}
\hline age & 5.7 & 5.8 & 5.9 & 5.10 & 5.11 & 6.0 \\
\hline place & 26.4 & 22.2 & 33.3 & 25.5 & 22.4 & 31 \\
\hline time & 24.5 & 24.4 & 23.3 & 29.8 & 36.2 & 38.1 \\
\hline manner & 18.9 & 24.4 & 23.3 & 23.4 & 19 & 7.1 \\
\hline degree & 20.8 & 20 & 13.3 & 12.8 & 15.5 & 16.7 \\
\hline cause & 3.8 & 2.2 & 3.3 & 2.1 & 1.7 & 2.4 \\
\hline predicatives & 3.8 & 4.4 & 1.7 & 2.1 & 3.4 & 2.4 \\
\hline addition & 1.9 & 2.2 & 1.7 & 4.3 & 1.7 & 2.4 \\
\hline total & 53 & 45 & 60 & 47 & 58 & 42 \\
\hline
\end{tabular}

\section{Table 4: Continuation}

\subsubsection{Adverbs of place}

Adverbs of place belong to the most frequently occurring group of adverbs with the highest number of lemmas used. This fact was most apparent at the very beginning; in later development, other types of adverbs (especially time adverbs) also become frequent. Among adverbs of place, adverbs denoting location were more frequent than adverbs denoting direction. The most frequently occurring adverbs during the whole period were the adverbs tady / here (and its colloquial variants tadyhle, tajdle), tu / here and tam / there, which can be used both in locative and directive meanings, and the interrogative kde / where, kam / where to and pryč /away, denoting both location and direction. The following is a list of examples of adverbs that were first used at particular ages of Premysl's development (adverbs that have been commented on in section 4.1 are not included):

Adverbs denoting location that were first used between the ages of 3.1 and 4.0 include the following: jinde / somewhere else; dole / down; doma / at home; někde / somewhere; nahore / up, in higher places; vevnitř / inside; všude / everywhere; and vedle / beside; the adverb denoting direction that was first used between the ages of 3.1 and 4.0 was nikam / to nowhere.

Adverbs denoting location that were first used between the ages of 4.1 and 5.0 included the following: kolem / around; adverbs denoting direction included the following: někam / somewhere, zpátky / back; nahoru / upwards; domů / home; jinam / somewhere else; and blíz / closer. At age 4.5 , the following adverb denoting focus appeared: zblízka / from near.

Adverbs denoting location that were first used between the ages of 5.1 and 6.0 included the following: blizko / near; nikde / nowhere; vzadu / at the back; and okolo / around; adverbs denoting direction that appeared at this age included the following: stranou / aside and zpět / backwards; the interrogative adverb kudy 
/ which way appeared first at age 5.9. In summary, the most frequently used adverbs of place included pronominal adverbs (tam / there, tady / here), interrogative adverbs (kde / where, kam / where to), negative adverbs (nikde / nowhere, nikam / (to) nowhere) and shifters (jinde / somewhere else, jinam / (to) somewhere else). All these adverbs are deictic and can be combined with gestures. In the context in which all the interactants see the referents, the frequent usage of deictical elements is typical. For expressing more precise spatial meanings, the child used combinations of prepositions and nouns rather than adverbs as soon as he had acquired nominal declension. Apart from pronominal adverbs, the child used several adverbs denoting concrete spatial relationships, usually involving both location and direction (ven / out, venku / outside, dole / down-location, dolu / downdirection, doma / at home, and domu / home). More elaborate spatial relationships such as focus (zblizka / from near) or describing a way (kudy / which way) ware rare and occurred at later stages of language ontogenesis.

\subsubsection{Adverbs of time}

From the first audio recordings, the adverbs už and ještě occurred frequently in the child's speech. Because these adverbs are multifunctional, I will provide examples of their usage:

age 2.8 .16

(2) nožky už má leg-acc. pl. diminutive + adverb už + have-3sg. present

'he already has legs' (when drawing a teddy bear)

(3) už neni žlutá adverb už + be-3sg. present negated + yellow-nom. sg. fem.

'there is no more yellow' (colour)

age 4.0.17

(4) už začíná pršet adverb už + start+3sg. present + raininf.

'it just starts raining'

(5) už to nechci adverb už + it-acc. sg. + want-1 sg. negated
'I do not want it anymore'

usage of adverb ještě (colloquial eště)

age 2.8 .16

(6) eště je to špinavý

adverb eště + be-3sg. present + itnom. sg. + dirty-nom. sg. neuter (Common Czech)

'it is still dirty'

(7) eště jedna

adverb eště + one-nom. sg. feminine

'there is one more' (cube)

age 4.0.17

(8) a co eště můžem zkusit vyrobit?

and + what + adverb eště + can- 1 pl.

present + try-inf. + make-inf.

Among the most frequent adverbs throughout the child's pre-school age were ted'(ka) / now and pak, potom / then, thereafter. Additionally, the adverbs dnes(ka) / today, zejtra / tomorrow (Common Czech) and včera / yesterday were used, as well as adverbs denoting parts of the day, such as večer / in the evening and dopoledne / forenoon. The interrogative $k d y$ / when was frequent. Adverbs denoting repetition were also among the most frequent adverbs used from the beginning of the audio recording: zase, znova / again.

Adverbs denoting temporal aspects that were first used between ages 3.1 and 4.0 included the following: nejdriv / first, at the earliest; vždycky / always; zatím / meanwhile; furt / all the time (Common Czech); brzy / soon; často / often; letos / this year; konečně / finally; hned / immediately; poŕád / all the time; prve / previously; naposled / for the last time; dlouho / for a long time; nikdy / never; tenkrát / back then; někdy / sometimes; nakonec / in the end; and minule / last time.

Adverbs denoting temporal aspects that were recorded between ages 4.1 and 5.0 included the following: predevčirem / the day before yesterday; teprv / just; príště / next time; pozdě / late; predtím / before; and denně / daily. Adverbs denoting temporal aspects that were first used between ages 5.1 and 6.0 included the following: nedávno / recently; najednou / suddenly; onehdy / the other day 
(bookish); dokud / as long as; drív / earlier; rovnou / straightaway; navždycky / forever; stále / constantly; and přiště / next time.

In summary, the child developed a rather complex system of time adverbs, which referred to the present time at first. Compared to adverbs of place, the development of time adverbs started slightly later but finally yielded a greater variety. The child started using adverbs referring to the future sooner than using adverbs referring to the past, and the first contrasts made were between present and future: pak, potom / then, thereafter in contrast to ted' / now; zejtra / tomorrow in contrast to dnes / today. Adverbs connecting the past and present, prototypically referring to some achievement (už - something already exists; ještě - something still lasts), were used earlier than adverbs referring to the past. Finally, adverbs referring to the past were also elaborated, and the child used adverbs of various stylistic levels (colloquial, neutral and also bookish). However, the child was perhaps unaware of their stylistic value. Interestingly, I did not notice any overextension of usage; deictic adverbs such as dnes / today, včera / yesterday or predevčírem / the day before yesterday seem to be used appropriately.

\subsubsection{Adverbs of manner}

In the audio recordings, from the outset, pronominal adverbs of manner tak, takhle / this way and the interrogative jak / how and jinak / the other way were among the most frequent.

Adverbs of manner that were first used between the ages of 3.1 and 4.0 included the following: dobre / well; našišato / unevenly, irregularly, nějak (colloquial ňák) / somehow; blbě / stupidly; opravdu / really; hezky / nicely; and nejradši / the most preferably. Between the ages of 4.1 and 5.0, the following adverbs were recorded: tiše / quietly; jistě / certainly; špatně / badly; rychle / quicky; pomalu / slowly; líp / better; zadarmo / for free, stejně / equally; pořádně / properly; nejrychlejc (Common Czech) / most quickly; and určitě / surely; colour-related terms were also used, for example malovat hnědè, žlutě / to colour brown, yellow. Adverbs of manner that were first used between the ages of 5.1 and 6.0 were the following: hlavnè / mainly; pečlivě, pečlivějc / carefully, more carefully; správně / correctly; pomèrně / relatively; hüř / worse; pěšky / on foot, and samozrejmè / of course.

Adverbs of manner express a variety of meanings, most of which are derived from adjectives. In some contexts, both adjectives and adverbs can be used with similar meanings:

Je to dobré (dobrý in Common Czech) / 'It is good' (adj.)

Je to dobre / 'It is well' (adv.)

The use frequency of adverbs of manner was lower than the use frequency of other types of adverbs because the child preferred to use adjectives when possible. In addition, the meaning of adverbs of manner is often abstract; therefore, these adverbs were developed later than adverbs with more concrete meanings (such as adverbs of place). Some adverbs of manner can form comparatives and superlatives and also appeared in the child's production. However, the first forms were suppletive (dobre / well; líp / better; špatně / badly and hür / worse). Regular forms of comparatives and superlatives first appeared after age 5 (pečlivě, pečlivějc / carefully, more carefully, and rychle, nejrychlejc / quickly, most quickly).

Semantically, the child expressed evaluation in a broader sense (dobre / well and hezky / nicely), concrete meanings (colour terms, commenting on speed or loudness) and, in later development, modality (jistě / certainly and určitè / surely). To conclude, the most abstract (modal) aspects were the latest to develop, and the most complex forms (comparatives and superlatives) were used at a later stage.

\subsubsection{Adverbs of degree}

Adverbs of degree were frequently used; after the child achieved 300 lexemes in his active vocabulary, he began to add new (often synonymous) lexemes denoting degree or measure. Among the most frequent of these were the following: hodně / much, many; moc / very much, a lot; málo / little, not much; trochu, trošku / a little bit; jen, jenom / only; úplně / completely; and dost / enough.

Adverbs of degree that were first used 
between the ages of 3.1 and 4.0 were the following: navíc / in addition; ohromnè / tremendously; strašlivě / terribly; nejvíc / most; víc / more; and akorát (colloquial) / just, precisely. Between the ages of 4.1 and 5.0, the following adverbs of degree were recorded: plno / plenty; šileně / awfully; skoro / nearly; mín / less; hrozně / horribly; málem / almost; docela / quite; príliš / too (much); and trošičku / a little bit (diminutive). Between the ages of 5.1 and 6.0, the following adverbs were first used: obzvláśt' / especially; většinou / mostly; příšerně / terribly; strašně / horribly; stejně / equally, just as; and spoustu / loads of.

Expressing degree was very important for the child throughout the analysed period. In the audio recordings, expressions referring to higher degree were usually more frequent than those referring to lower degree. To express the highest degree, number or measure, the child often used colloquial, marked expressions, such as príšernè moc / terribly many and strašlivě / horribly etc. In Czech, adverbs of degree can refer to both countable and mass nouns; thus, no errors in countability occurred:

moc, málo hraček / many, few toys moc, málo vody / much, little water

Suppletive comparatives and superlatives, such as víc, nejvíc / more, most and miń / less were first used after 3 years of age and were used earlier than the comparative and superlative forms of adverbs of manner. No errors in the active usage of adverbs of degree were noted.

\subsubsection{Adverbs of cause}

From the age of 3.1 , the interrogative adverb proč / why was one of the most frequently used adverbs. At age 5.5, the adverb schválně / deliberately was recorded, and at age 5.7, the adverb zbytečně / needlessly was used. The usage of these adverbs was rare throughout the pre-school period. Adverbs of cause are generally rare even in adult language.

\subsubsection{Predicatives}

From age 3.9 , the child frequently used the modal predicative potreba / need(ed):

(9) proč je potřeba?

why + be-3sg present + predicative adverb

'why is it needed?'

From age 3.10 , state predicative škoda / pity was used:
(10) škoda Bomba
predicative adverb + name of the toy- gen. sg. mas.
'it is a pity that the toy Bomb is damaged'

From age 5, predicatives expressing feelings also started to be used:
(1 1 ) mně je to líto
I-dat. sg. + be-3sg. present + it-nom.
sg. + predicative adverb
'I feel sorry'

\subsubsection{Adverbs expressing addition or inclusion}

Adverbs denoting addition or inclusion were appropriately used from the beginning of the audio recordings. The adverb taky / too appeared among the first 400 lexemes in the child's vocabulary acquisition. From age 2.6, this adverb was among the most frequently used. At age 4.10, the adverb dohromady / together was recorded, and at age 4.8, the adverb spolu / with each other was used.

\subsubsection{The type-token ratio of adverbs} The type-token ratio (TTR) is used in quantitative linguistics as the basic indicator of vocabulary diversification in a particular text. In child language research, the index is used as an indicator of vocabulary development in child speech. If the number of lexemes is small, lexemes are often repeated, and the TTR index is higher. In contrast, a higher number of lexemes compared to all occurrences of lexemes will result in a lower TTR index, indicating a more diverse vocabulary (Průcha, 2011, p.182). In Table 5, the TTR development of adverbs is presented. Lemma ( $L$ ) represents the number of adverb lemmas in an analysed one-month period; all lexemes in the transcription were counted. Token $(\mathrm{N})$ represents the number of all adverb tokens in all grammatical forms; all adverb tokens in the entire transcript were counted. TTR = $\mathrm{N} / \mathrm{L}$. Generally, the results show that the index did not decrease significantly, and repetition remained high. The most 
frequent adverbs were frequently repeated. However, the number of lexemes (lemmas) increased significantly from, for example, 9 lexemes at age 2.9 to 58 lexemes at age 5.11. More concretely, the boy continuously added new adverbial lexemes to his vocabulary, but the index of repetition remained high for deictic adverbs of place (tam / there and tady / here), adverbs of time (už / already, yet, any more, as early as.... and ještě / still, yet, as late as, even more, once again), and the adverbs taky / too and proč / why.

\begin{tabular}{|l|l|l|l|l|l|l|l|l|l|l|l|l|}
\hline age & 2.8 & 2.9. & 2.10 & 2.11 & 3.0 & 3.1 & 3.2 & 3.3 & 3.4 & 3.5 & 3.6 & 3.7 \\
\hline token N & 68 & 79 & 70 & 152 & 74 & 89 & 60 & 155 & 122 & 156 & 229 & 249 \\
\hline lemmas & 13 & 9 & 11 & 11 & 15 & 15 & 18 & 25 & 20 & 30 & 31 & 29 \\
\hline TTR & 5.2 & 8.8 & 6.4 & 13.8 & 4.9 & 5.9 & 3.3 & 6.2 & 6.1 & 5.2 & 7.4 & 8.6 \\
\hline
\end{tabular}

Table 5: Type - token ratio in adverbs

\begin{tabular}{|l|l|l|l|l|l|l|l|l|l|l|l|l|}
\hline age & 3.8 & 3.9. & 3.10 & 3.11 & 4.0 & 4.1 & 4.2 & 4.3 & 4.4 & 4.5 & 4.6 & 4.7 \\
\hline token N & 352 & 248 & 226 & 138 & 241 & 263 & 312 & 257 & 186 & 269 & 222 & 224 \\
\hline lemmas & 37 & 31 & 33 & 27 & 50 & 30 & 39 & 39 & 30 & 33 & 28 & 46 \\
\hline TTR & 9.5 & 8 & 6.8 & 5.1 & 4.8 & 8.8 & 8 & 6.6 & 6.2 & 8.2 & 7.9 & 4.9 \\
\hline
\end{tabular}

Table 5: Continuation

\begin{tabular}{|l|l|l|l|l|l|l|l|l|l|l|l|}
\hline age & 4.8 & 4.9 & 4.10 & 4.11 & 5.0 & 5.1 & 5.2 & 5.3 & 5.4 & 5.5 & 5.6 \\
\hline token N & 293 & 394 & 284 & 192 & 192 & 302 & 254 & 299 & 264 & 294 & 459 \\
\hline lemmas & 57 & 57 & 49 & 44 & 40 & 48 & 43 & 50 & 47 & 37 & 48 \\
\hline TTR & 5.1 & 6.9 & 5.8 & 4.4 & 4.8 & 6.3 & 5.9 & 6 & 5.6 & 7.9 & 9.6 \\
\hline
\end{tabular}

Table 5: Continuation

\begin{tabular}{|l|l|l|l|l|l|l|}
\hline age & 5.7 & 5.8 & 5.9 & 5.10 & 5.11 & 6.0 \\
\hline token N & 352 & 335 & 306 & 170 & 301 & 207 \\
\hline lemmas & 53 & 45 & 60 & 47 & 58 & 42 \\
\hline TTR & 6.6 & 7.4 & 5.1 & 3.6 & 5.2 & 4.9 \\
\hline
\end{tabular}

Table 5: Continuation

\section{Discussion and conclusions}

In this section, research questions will be discussed, and the development of adverbs will be linked to the development of nominal and verbal grammatical categories. The first research question addressed the acquisition sequence of semantic adverb categories. Adverbs of place were used first, direction was expressed before location, and, during later development, location was more frequent than direction. Pronominal deictic adverbs were among the first adverbs used and were among the most frequent throughout the analysed period, which was also reported for Slovak (Kesselová and Slančová, 2014). The information concerning location may be found in a variety of devices, such as spatial prepositions or postpositions, as well other parts of the clause, such as the verb or a variety of morphological markings (Hickmann, 2001, p.115). In our sample, spatial relations were also expressed by combinations of prepositions and nouns. The boy started to use constructions involving prepositions and nouns in various cases (typically locative) to express spatial relation at age 2.9 (Chejnová, 2016a). At this age, the percentage of adverbs of place decreased $(53.8 \%$ at age 2.8 versus $33.3 \%$ at age 2.9 ). Thus, as soon as the child had a more precise means of expressing spatial relationships at his disposal, he began to use it in parallel with adverbs of place that have a broader meaning. Although this finding is interesting, based on the limited data, it cannot be claimed that the drop in frequency of particular adverbial types has only been influenced by the acquisition of other linguistic devices. This claim requires further validation.

Second, adverbs of time appeared, denoting location in time and the achievement of some point in time or repetition. The boy started using adverbs referring to the future sooner than adverbs referring to the past. Adverbs referring to some achievement ( $u z ̌$ / already; ještě / more, again) were also used earlier than those referring to the 
past. An interesting correlation between the development of adverbs and the development of verbal grammatical categories was observed. Considering the acquisition sequence of verbal categories, the boy started to use the future tense of the verbs být / to be and mít / to have, which were the first verbs to develop contrastive forms, earlier than the past tense. The first tenses that were acquired for lexical verbs were the present tense of imperfective verbs and the future tense of perfective verbs (both synthetic). Nevertheless, the first grammatical contrasts expressed by lexical verbs included the following: the infinitive in the directive function, $3 \mathrm{sg}$. the present tense in imperfective verbs, $3 \mathrm{sg}$. the future tense of perfective verbs ${ }^{2}$ and the past participles of all three genders. Thus, the preference for words involving the future was manifest only during the earliest, premorphological stage. At age 3.2, the percentage of adverbs of time decreased ( $40 \%$ at age 3.1 versus $22.2 \%$ at age 3.2 ). At age 3.2, the child started to form aspect oppositions (Chejnová, 2016a; 2016b). In Czech, aspect is an inherent category that is present in every verb irrespective of its form; verbs are inherently perfective or imperfective and usually form pairs of perfective and imperfective verbs that have similar meanings apart from aspect (zavrít versus zavirat / to open versus to be opening). This fact could be interpreted as evidence that when a new, more precise means of expressing time relationships (or achievement) was acquired, the child began to use it in parallel with broader adverbial expressions.

Third, adverbs of degree appeared; the first were adverbs expressing low degree. In concordance with previous research, expressing higher degree was more frequent than expressing lower degree, except at the very beginning. Adverbs of manner appeared last, and among the most frequent were those with a broader evaluative sense. Adverbs of cause were mostly represented by the interrogative proč / why. Predicatives expressing modal aspects and states (potreba / needed,

\footnotetext{
${ }^{2}$ Perfective verbs do not form the periphrastic future; the future tense has the form of the present tense; perfective verbs are not used in the present tense in Czech.
}

škoda /pity) were used by ages 3.9 and 3.10 , respectively, whereas predicatives expressing feelings (líto / sorry) were used only at age 5 , probably due to their rather abstract meaning and their references to emotional states, an understanding of which is dependent on cognitive development in general.

The second research question addressed the frequency of adverbial types. Considering the frequency of lemmas (types), adverbs of place were the most frequent adverbs at the beginning of adverbial acquisition, whereas during the protomorphological stage and the modularized morphology stage, adverbs of place and adverbs of time were similar in frequency and were the most frequently used adverbs. The number of adverbs of manner and degree was lower in most audio recordings. Adverbs of cause were represented mostly by the interrogative proč / why, and adverbs denoting addition were represented by the adverb taky / too. Considering the number of tokens, the index of repetition was high for some adverbs throughout the analysed period. These adverbs primarily included deictic adverbs of place (tam / there and tady / here). Their deictic function makes these adverbs multifunctional; thus, it is easier for the child to refer to a particular space using these adverbs than by specifying the space using a more precise combination of a preposition and noun. The adverbs of time už / already, yet, any more, as early as... and ještě / still, yet, as late as, even more, once again were also often repeated. These adverbs are also multifunctional and thus enabled the child to express a variety of meanings (see section 5.2.3). The adverb proč / why was also very frequent and was typically used for omnipresent child questions that serve mainly communicative purposes. On the other hand, adverbs that carry narrow meanings were not often repeated.

The last research question was focused on errors in adverb usage. Surprisingly, no errors were noted in the child's spontaneous production of adverbs; however, the audio recordings covered only a small portion of overall speech production. Thus, some overextension might have occurred without being noticed. Because comprehension was not tested, it cannot be claimed that the child's understanding was identical to 
adult understanding. Although the study yielded relevant results, it represents an analysis of one child's language development. An analysis of the verbal productions of more children is needed to validate the results.

\section{Acknowledgement}

I would like to express my thanks to the editors of Topics in Linguistics and the anonymous reviewers for their helpful comments.

\section{References}

AMIDON, A. and CAREY, P., 1972. Why five years olds cannot understand before and after. Journal of Verbal Learning and Verbal Behaviour, vol. 11, pp. 417-423.

BARRIE-BLACKLEY, S., 1973. Six-year old children's understanding of sentences adjoined with time adverbs. Journal of Psycholinguistic Research, vol. 2, no. 2, pp. 153-165.

BITTNER, D., DRESSLER, W. U. and KILANI-SCHOCH, M., eds., 2003. Development of verb inflection in first language acquisition. A cross-linguistic perspective. Berlin: Mouton-de Gruyter.

BROWN, A. and FRENCH, L., 1976. Construction and regeneration of logical sequences using causes of consequences as the point of departure. Child Development, vol. 47, no. 4, pp. 930-940.

CARNI, E. and FRENCH, L., 1984. The acquisition of before and after reconsidered: What develops. Journal of Experimental Child Psychology, vol. 37, no. 2, pp. 394-403.

CHEJNOVÁ, P., 2015. Development of directives in child language - A case study of Czech. Topics in Linguistics, vol. 15, no. 1.

CHEJNOVÁ, P., 2016a. Acquisition of morphological categories and vocabulary in early ontogenesis of a Czech child. Praha: Karolinum.

CHEJNOVÁ, P., 2016b. Osvojování gramatických kategorií sloves u českého dítěte. Slovo a slovesnost, vol. 77, no. 3, pp. 185-201.

CLARK, E. V., 1971. On the acquisition of before and after. Journal of Verbal Learning and Verbal Behavior, vol. 10, pp. 266-275.

COKER, P., 1978. Syntactic and semantic factors in the acquisition of before and after. Journal of Child Language, vol. 5, no. 2, pp. 261-277.

DRESSLER, W. U., ed., 1997. Studies in Pre- and Protomorphology. Wien: Verlag der Österreichischen Akademie der Wissenschaften.

FRENCH, L. and NELSON, K., 1983. Ifs, ors and buts about preschoolers' understanding of relational terms. Unpublished manuscript, University of Rochester.

HARNER, L., 1975. Yesterday and tomorrow: Development of early understanding of the terms. Developmental psychology, vol. 11, no. 6, pp. 864-865.

HICKMANN, M. 2001. Language and cognition in development: Old questions, new directions. Pragmatics, vol. 11, no. 2, pp.105-126.

KARLíK, P., NEKULA, M. and RUSínOVÁ, Z. eds., 2002. Příruční mluvnice češtiny. Praha: Nakladatelství Lidové noviny.

KESSELOVÁ, J., 1999. Komunikačná funkcia adverbií v spontánnom dialógu detí. In: P. Odaloš, ed. Retrospektívne a perspektívne pohlady na jazykovú komunikáciu. II. diel. Materiály z 3. konferencie o komunikácii. Banská Bystrica - Donovaly: Pedagogická fakulta Univerzity Mateja Bela a Fakulta humanitných vied Univerzity Mateja Bela, pp. 100-106.

KESSELOVÁ, J., 2010. Priestor a čas v ranej ontogenéze reči. In: S. Čmejrková, J. Hoffmannová, E. Havlová, eds. Užívaní a prožívaní jazyka. K 90. narozeninám Františka Daneše. Praha: Karolinum, pp. 467-471.

KESSELOVÁ, J. and SLANČOVÁ, D., 2014. Priestor v ranej ontogenéze reči dietatáa. $O$ diet'ati, jazyku, literatúre: časopis pre otázky rozvíjania komunikačnej a literárnej kompetencie, vol. 2, no 1, pp. 7-20.

KOMÁREK, M., KOŘENSKÝ, J., PETR, J. and VESELKOVÁ, J., eds., 1986. Mluvnice češtiny II Tvarosloví. Praha: Academia.

LUST, B., 2006. Child language. acquisition and growth. Cambridge: Cambridge University Press.

MacWHINNEY, B. and SNOW, C., 1985. The child language data exchange system. Journal of Child Language, vol. 12, pp. 271-296. 
MacWHINNEY, B., SNOW, C., 1990. The Child Language Exchange System. An Update. Journal of Child Language, vol. 17, pp. 457-472.

MANDIĆ, M., 2011. The extension of meaning of temporal adverbs in Serbian-speaking children aged 1;6 to 4;0. In: M. Brdar, M. Omazić, V. Pavičić Takač, T. Gradečak-Erdeljić, G. Buljan, eds. Space and Time in Language. Frankfurt am Main: Peter Lang GmbH, pp. 297312.

NEUSTUPNÝ, J. V. and NEKVAPIL, J., 2003. Language Management in the Czech Republic. Current Issues in Language Planning, 4, 181-366. Reprinted 2006 In: R. B. Baldauf and R. B. Kaplan, eds. Language planning and policy in Europe 2: The Czech Republic, the European Union and Northern Ireland. Clevedon: Multilingual Matters, pp. 16-201.

PAČESOVÁ, J., 1968. The development of vocabulary in the child. Brno: Univerzita J. E. Purkyně.

PAČESOVÁ, J., 1979. Řeč v raném dětství. Brno: Univerzita J. E. Purkyně.

PIAGET, J. and INHELDER, B.,1969. The psychology of the child. New York: Basic Books.

PRŮCHA, J., 2011. Dětská řeč a komunikace. Poznatky vývojové psycholingvistiky. Praha: Grada Publishing.

SAICOVÁ ŘíMALOVÁ, L., 2013. Když začínáme mluvit...Lingvistický pohled na rané projevy česky hovořícího dítěte. Praha: Filozofická fakulta Univerzity Karlovy.

STEPHANY, U. and VOEIKOVA, M. D., eds., 2009. Development of nominal inflection in first language acquisition: A cross-linguistic perspective. Berlin, New York: Mouton de Gruyter.

VOEIKOVA, M. D. and DRESSLER, W. U., eds., 2002. Pre- and Protomorphology. Early phases of morphological development in nouns and verbs. München: Lincom Europa.

http://childes.psy.cmu.edu/ [Accessed 1 July 2016].

http://laboratorium.detskarec.sk/ [Accessed 1 July 2016].

\section{Authors' address and contact details}

PhDr. Pavla Chejnová, Ph.D.

Charles University - Faculty of Education

M. D. Rettigové 4

11639 Praha 1

Czech Republic

E-mail: pavla.chejnova@pedf.cuni.cz 